\title{
Clarice Lispector em Felicidade clandestina: a poética do eu*
}

Fecha de recepción: 01 de marzo de 2017

Fecha de aprobación: 27 de abril de 2017

\section{Resumo}

Este artigo trata da aproximação dos planos da realidade e da fantasia, especialmente no conto "Felicidade Clandestina", publicado no livro com o mesmo título, em que os dois segmentos passam a disputar o mesmo espaço. A realidade de uma mulher adulta que resgata fantasias da infância de uma época em que, como personagem, foi submetida a brincadeiras imprevisíveis em que foi objeto de zombarias, chegando a situações constrangedoras em uma passividade que, por vezes, lembra a de uma presa acuada. No entanto, a própria protagonista, antes submetida à astúcia da colega de escola, agora na posição de narradora, exerce pleno controle sobre o leitor. Passa de personagem a construtora do texto, jogandcom os sentidos daquele que está imerso na história fictícia.

Palavras-chave: Crítica biográfica; relações literárias; autoficção; Clarice Lispector; narrativas do eu

Citar: Machado García, L. (enero-junio de 2017). Clarice Lispector em "Felicidade clandestina": a poética do eu. La Palabra, (30), 217 - 230. doi: https://doi. org/10.19053/01218530.n30.2017.6332

\section{Lucilene Machado García}

Doutora em Teoria Literária, Universidade Estadual de São Paulo. Professora Adjunta no Curso de Letras/Espanhol na Universidade Federal de Mato Grosso do Sul e Programa de Mestrado em Estudos Fronteiriços.

lucilenemachado@terra.com.br

*Artículo de reflexión 


\section{la palabra}

\section{Clarice Lispector em Felicidade clandestina: a poética do eu}

\section{Resumen}

Este artículo trata de aproximar dos planos de realidad y fantasía, en el cuento "Felicidade Clandestina" publicado en el libro con el mismo título, donde estos dos aspectos pasan a disputar un mismo espacio. El cuento presenta la realidad de una mujer adulta que rescata fantasías de la infancia en un tiempo en que, como personaje fue sometida a juegos imprevisibles, en los que es objeto de burla, llegando a situaciones preocupantes, en una pasividad que, a veces recuerda a una presa atrapada. Sin embargo, la misma protagonista antes sometida a la crueldad de su compañera de colegio, ahora en la posición de narradora, ejerce pleno control sobre el lector. Pasa de ser personaje a constructora del texto, jugando con los sentidos de aquel que está inmerso en la historia ficticia.

Palabras clave: Crítica biográfica, relaciones literarias, autoficción, Clarice Lispector, narrativas del yo.

\section{Clarice Lispector in "Felicidade Clandestina" [Clandestine Happiness]: a Poetics of the Self}

\section{Abstract}

This article attempts to approximate two planes: reality and fantasy, in the story "Clandestine Happiness" published in the book with the same title. This story narrates the reality of an adult woman who explores childhood fantasies in a time in which she is subjected to cruel games of mockery, that develop to a preocupying level, in a passivity that sometimes reminds the reader of a trapped prey. Nevertheless, the same protagonist who was once subjected to her classmate's cunning, now exercises full control in the position of narrator before her readers. She passes from character to constructor of the text, playing with the senses of the reader who is now engaged in the fictional story.

Keywords: Biographical criticism, Literary relations, Autofiction, Clarice Lispector, Narratives of the Self. 


\section{Clarice Lispector dans Bonheur clandestin: une poétique du moi}

\section{Résumé}

Dans cet article nous nous intéressons aux plans du réel et de la fiction dans la nouvelle Bonheur clandestin de Clarice Lispector, issue du livre portant le même titre. Une femme retrouve des illusions d'enfance alors qu'elle est soumise à des jeux imprévisibles, traitée avec sarcasme dans des situations déchirantes, dans une passivité qui fait penser à une proie tremblante. Néanmoins, le même personnage principal, ayant été soumise à l'astuce de sa camarade de classe, maintenant exerce le contrôle sur le lecteur en tant que narrateur. Elle change de personnage, elle devient celle qui construit le texte et joue avec celui qui est en train de lire l'histoire.

Mots-clés: critique biographique, repports littéraires, autofiction, Clarice Lispector, narrations du moi.

\section{Introdução}

O conto "Felicidade Clandestina", de Clarice Lispector, está inserido no volume homônimo publicado em 1971, no qual a maioria dos textos está voltada para questões que visam compreender o universo adolescente, envolvendo ansiedades, descobertas e inquietações daqueles que ainda precocemente anseiam por tatear o mundo, habitando desde cedo o marginalizado território da clandestinidade. "Felicidade Clandestina" estrutura-se em torno de um caso de pré-adolescência, vivenciado na cidade de Recife pela personagem-narradora, a própria Clarice, que registra impressões de uma mulher que, menina ainda, lera um livro conseguido como empréstimo.

O mais relevante é a constatação de que tal acontecimento narrado no conto acontecera realmente com a leitora-menina Clarice, como atesta sua biografia. Desde já, e por isso mesmo, cabe-nos dizer que nossa leitura privilegiará os postulados críticos defendidos pela crítica biográfica. Crítica essa que, por sua própria natureza, não se vale só da ficção, mas toma o não-ficcional na mesma proporção. Em vista do exposto, nossa leitura leva em conta tal traço biográfico acontecido na infância com a escritora em cotejo. Assim, valer-nos-emos da própria obra de Clarice, na qual se encontra intrínseca uma espécie de biografia que não é apenas biografia circunstancial, mas que subsiste e torna-se intrigante na medida em que acompanhamos seu pensamento e percebemos que certo teor nos depoimentos não é incompatível (não pode ser) com a forte presença humana, as coisas e a história dessa mulher que é uma das maiores expressões enigmáticas da literatura brasileira de todos os tempos.

Sua presença na obra não é uma presença abstrata - antes, pelo contrário, é percebida na concretude e imediatez com que dá voz às personagens. E, por isso, na fronteira entre vida e ficção, e em que esta se apresenta fundamentalmente como uma modalidade marcada daquela, podemos falar de uma instância biográfica que é implicada pela ficção, não no sentido em que personaliza e subjetiviza, mas porque atesta a presença de uma dimensão vivencial que torna tal experiência comunicável e partilhável.

Assim, os momentos que podemos escolher, entre os vários que escandem a vida de Lispector, dão-nos, sobretudo, conta 
de um conjunto de opções que não se esgota em sua narrativa. No texto "Felicidade clandestina", Clarice, no papel de protagonista, diz: "guiava-me a promessa do livro, o dia seguinte viria, os dias seguintes seriam mais tarde a minha vida inteira, o amor pelo mundo"(Lispector,1998, p.10), o que nos leva desde logo a perceber que o terreno em que a escritora se move não se isola dos modos de vida seus e dos outros. E que os seus modos de vida fazem parte da ligação íntima que sua escrita tem com as coisas do mundo.

Nesse exercício de encontrar a voz da Clarice autora e tantas outras clarices que ora aparecem, ora fogem, ora parecem rir de todos nós, encontramos também vozes das escritoras Virginia Woolf e Katherine Mansfield, cujos textos, ancorados em algum tipo de "felicidade", dialogam com a autora brasileira.

\section{A verdade literária}

A autora de Felicidade Clandestina instala no conto com o mesmo título o plano da realidade e o da fantasia que passam a disputar o mesmo espaço. A realidade de uma mulher adulta que resgata fantasias da infância num curso de tempo em que, como personagem, fora submetida a imprevisíveis jogos, tratada com ludíbrio, chegando a situações consternadoras, numa passividade que, por vezes, lembra uma presa acuada. No entanto, a mesma protagonista antes submetida à astúcia da colega de escola, agora na posição de narradora, exerce pleno controle sobre o leitor. Passa de personagem à construtora do texto, jogando com os sentidos daquele que está imerso na história fictícia. E, à medida que ficção/realidade passam despercebida, a verdade latente que se constrói é a verdade do leitor. A realidade criada pela imaginação engloba a realidade do fato e a realidade externa ao fato que, supõe-se verídica. $\mathrm{O}$ que permite presumir que a distância entre vida e obra de Clarice é bastante exígua e reitera o princípio da criação artística relacionado à criação de fábulas biográficas.

O fascínio que envolve a invenção de biografias literárias se justifica pela natureza criativa dos procedimentos analíticos, em especial, a articulação entre obra e vida, realizada através de associações de ordem metafórica. Consegue-se tornar infinito o exercício ficcional do vasto texto da literatura, graças à abertura de portas que a transcendem. (Souza, 1999, p. 85)

A escrita de Clarice em "Felicidade clandestina" ocupa o espaço do presente, é uma escrita no gerúndio: "era um livro para se ficar vivendo com ele, comen- do-o, dormindo-o" (p. 25). O tempo verbal provoca a impressão de que ela está escrevendo à nossa frente, diante do leitor, para revelar em sua total nudez, em seu pungente desamparo, o próprio ato de escrever. É como se ela tivesse feito do delírio de Marguerite Duras um método - não para rememorar vicissitudes ou aventuras, mas para pensar, com o leitor, a vida de todos nós. Clarice não apenas conta (sua) história, mas escreve a vida e escreve o escrever. Segundo Duras, "é preciso ser mais forte do que si mesma para abordar a escrita (...) Não é apenas a escrita, o escrito, é o grito das feras noturnas, de todos, de você e eu, os gritos dos cães." (Duras, 1994, p. 23).

Esse conto, que se insere no possível, questiona, levanta dúvidas, revela, imprime segredos e reitera, o que já se comprovou, que, enquanto leitora, Clarice soube tirar proveito dos livros. Do conto, surge a intimidade com Monteiro Lobato, transformando-o no amante com o qual manteve essa relação clandestina e fictícia por toda a vida. No texto, emaranham-se a infância em Recife e a realidade da escritora adulta, passando esta a avaliar, desde então, o quanto a felicidade lhe foi clandestina.

Segundo Teresa Cristina Montero Ferreira, no ginásio, quando ainda morava em Recife, Clarice andava atrás de Revecca, filha do dono da livraria 
Imperatriz. "A colega tinha um livro cobiçado por Clarice há muito tempo: As reinações de Narizinho, de Monteiro Lobato. Percebendo o interesse de Clarice e sabendo de sua impossibilidade de comprá-lo, Revecca começou a exercer sobre ela uma "tortura chinesa" (1999, p. 25).

A tortura prolongada chega ao fim quando a senhora Berenstein, diante da outra filha Suzana, exige que Revecca empreste $\mathrm{o}$ livro à Clarice. A menina recebe, com lágrimas nos olhos, a melhor notícia do mundo: poderia ficar com o livro de Lobato por tempo indeterminado, como também todos os livros que quisesse.

No conto, como é comum nas fábulas, Clarice omite os nomes das personagens, mas a narrativa não foge aos fatos. Ao reconhecer que fora ludibriada pela filha do dono da livraria - como é chamada a menina no texto a escritora exerce sua vingança tardia. Como teorizou Cioran, ao falar sobre o exercício da escrita: "um clima de ajustes de contas em que as invectivas substituem as bofetadas e os golpes" (Cioran, 2000, p. 123). É como se Clarice tivesse recebido um insulto sem revidá-lo e agora devolvesse em palavras, submetendo a colega a um olhar humilhante, atacando até com certo sadismo, a mesquinhez da "filha do dono da livraria". O que pode ser justificado, ainda, nas palavras de Cioran: “escrever é desfazer-se de seus remorsos e rancores, vomitar seus segredos. O escritor é um desequilibrado que utiliza essas ficções que são as palavras para se curar. Quantas angústias, quantas crises sinistras venci graças a esses remédios insubstanciais" (p. 123). Não estaria Clarice também libertando-se de alguma mágoa, alguma culpa ou, até mesmo fazendo lembrar ao leitor que as diferenças de classes existem e que voltavam a assombrar sua memória, servindo-se de pano de fundo para suas ficções? De tudo, fica-nos evidente que Clarice soube tirar proveito de um caso pessoal banal, ocorrido na infância ao transformá-lo em conto, texto aparentemente despretensioso e ao mesmo tempo tão importante que dá título ao livro.

O enredo desenvolve-se como se ela tivesse conservado e desenvolvido esteticamente os pensamentos infantis, como se não tivesse esquecido o que é ser criança no mundo, naquilo que a criança tem de filósofa. E quando ela se detém na experiência amorosa, ou erótica, "segurava o livro grosso com as duas mãos, comprimindo-o contra o peito (...) era uma mulher com seu amante", o relato é o de uma iniciação, ou de uma ascese, como relata Foucault ao relembrar Santo Atanásio:

Eis uma coisa a observar para se ter certeza de não pecar. Que cada um de nós note e escreva as ações e movimentos da nossa alma, como que para no-los dar mutuamente a conhecer e que estejamos certos que, por vergonha de sermos conhecidos, deixaremos de pecar e de trazer no coração o que quer que seja de mais perverso. (Foucault, 1992, pp. $129-130)$.

Segundo Foucault, a escrita biográfica funciona como uma arma espiritual que dissipa a sombra interior onde se tecem as tramas do inimigo. Diante disso, pode-se compreender a ascese na escrita de Clarice não como uma mortificação do corpo, mas como uma iniciação, uma aprendizagem, transformação. Ou como reforça Ortega, "a ascese é um saber do sujeito que corresponde à sua atividade de autotransformação" (Ortega, 2000, p. 81). Segundo o estudioso, "trata-se de atualizar essa ascese, mas não apenas na acepção cristã e moderna (auto-renúncia, auto-restrição), mas no sentido mais amplo da filosofia greco-latina, como arte de vida, como auto-elaboração e auto-influência: a ascese como possibilidade de se equipar" (Foucault, 1999, p. 58). O próprio ato de escrever é vivido e revelado em um estado de consciência exaltada, exacerbada, que evoca uma singular e solitária experiência religiosa e mística. "Escrever é coisa sagrada 
onde os infiéis não têm entrada. (...) quando acabardes este livro chorai por mim um aleluia." (Lispector, 1978, p. 20). A mulher, que escrevia sentada no sofá numa máquina de escrever portátil Olympia, confessa através de seus personagens: "sei o que estou fazendo aqui: conto os instantes que pingam e são grossos de sangue" (Lispector, Água Viva, 1998, p. 21). Clarice tinha grande resistência para desprender-se de si: "eu vivo em carne viva, por isso procuro tanto dar pele grossa para meus personagens. (...) eu que escrevo para me livrar da carga difícil de uma pessoa ser ela mesma" (Lispector, 1978, pp. 15-16). A autora de Um sopro de vida prossegue deixando marcas de pessoalidade. Mas de súbito, num corte brusco, diz: "Eu que apareço neste livro não sou eu. Não é autobiográfico, vocês não sabem nada de mim." (p.19). Ainda mais intrigante é que na frase seguinte, ela substitui o pronome, anteriormente no plural, para o singular, flexiona o verbo na segunda pessoa e coloca-se no lugar do leitor: "Nunca te disse e nunca te direi quem sou. Eu sou vos mesmos" (p.19). Barthes assegura que "não há biografia a não ser a da vida improdutiva. Desde que produzo, desde que escrevo, é o próprio texto que me despoja (felizmente) da minha duração narrativa." (1977, p. 8.)

Clarice se dissolve nos texto com suas verdades reais ou in- ventadas. Intenta fazer do texto um objeto de prazer, tal como era para si o livro Reinações de Narizinho. Todo o seu esforço consiste em reduzir a distância entre a vida prática e a vida contemplativa. A ideia é de uma literatura em que estariam entrelaçadas, de maneira pessoal, a vida e o campo da ficção. Assim, narra com extrema sutileza os momentos de espera, o encontro com o livro, seu andar pelas ruas de Recife. O sonho sustenta a linha tênue das relações humanas e coloca em cena uma menina (Clarice/ personagem) sob o olhar de uma mulher (Clarice/escritora). Para Barthes,

Um certo prazer é tirado de uma maneira da pessoa se imaginar como indiví$d u o$, de inventar uma última ficção, das mais raras: o fictício da identidade. Essa ficção não é mais ilusão de uma unidade; é, ao contrário, o teatro de sociedade na qual fazemos comparecer nosso plural: nosso prazer é individualmas não pessoal. (Barthes, 2002, p. 73)

Diálogos literários de Lispector em "Felicidade Clandestina"

$\mathrm{O}$ encanto da protagonista de "Felicidade Clandestina" pelo livro, é o mesmo de Clarice. A escritora tinha imenso prazer na leitura. Percorria livrarias e bibliotecas de aluguel com esse fim. Tanto que ao receber seu primeiro ordenado como jornalista resolveu presentear-se com um livro intitulado Felicidade. Segundo Ferreira, ela entrou altiva na livraria, folheou vários livros até que abriu um e resolveu ler alguns trechos:

Todo aquele sentimento de felicidade voltou, e ainda uma vez, Bertha não sabia como expressar essa sensação, nem o que fazer com ela. Emocionada, interrompeu a leitura de $\mathrm{Fe}$ licidade e constatou: Mas esse livro sou eu!. E comprou-o imediatamente. Ignorava quem era a autora do livro. (Ferreira, 1999, pp. 74-75).

A obra era de autoria da neozelandesa Katherine Mansfield, com quem Clarice, posteriormente, dialogará ao escrever o conto, que remete ao mesmo título, em que ambas as personagens entregam-se a essa intensa sensação de felicidade, tendo os estados de êxtase também narrados com a mesma sensibilidade, além dos dois textos serem aclimatados na ambiência doméstica. Nádia Gotlib fala dessa identificação que Clarice sente em relação a Katherine e que se manifesta em muitos detalhes de construção narrativa. Katherine sofre de insociabilidade, "desenraizamento" entre outros males, mas, como Clarice, 
representa alegres e instantâneos flashes de um cotidiano singular, habitado por pombos, flores, árvores, cenas de família, lista de "coisas" ou "atos" a fazer no dia, galinhas, amigos, cozinheira, dificuldades do escrever, duas ou mais versões sobre um mesmo tema, morte, o inominável, além de um pavor da despersonalização. (Gotlib, 1995, p. 153).

Ricardo Iannace questiona o desconhecimento da obra declarado por Lispector: "mas o que haveria de especial na obra exposta sobre o balcão a ponto de despertar tanto fascínio em Clarice? Afinal, essa identificação com a contista "não era anônima" não se esvaiu naquele efusivo momento de descoberta da obra" (Iannace, 2001, p. 58). Certamente o fato de sentir-se atraída pelo livro, já estaria comprovando a predileção pela contista neozelandesa, cuja composição textual afina-se com a da escritora brasileira. Berta, a protagonista de "Felicidade" (Bliss), tem a mesma maneira altiva da personagem central de "Felicidade Clandestina", inclusive o mesmo modo de caminhar pelas ruas de Recife: "queria correr, ao invés de caminhar, executar passos de dança descendo e subindo a calçada" (Mansfield, 2000, p. 11), de forma semelhante narra Clarice: "eu recomeçava na rua a andar pulando, que era meu modo estranho de andar pelas ruas de Recife. (...) andei pulando pelas ruas como sempre e não caí nenhuma vez."

O escritor cubano Miguel Cossío Woodward, estudioso da obra de Clarice, disseminador de sua literatura na Espanha, e que agregou seu nome junto às Dez mulheres revolucionárias que contribuíram para revolucionar a arte literária com obras de indiscutível qualidade, ao lado de Virgínia Woolf, Simone de Beauvoir, Marguerite Yourcenar e Marguerite Duras, entre outras, disse sobre "Felicidade clandestina" o seguinte:

El cuento, que en su primera versión se llamó "Tortura y gloria", es también un pequeño homenaje a la célebre escritora neolandesa, cuyo relato "Bliss" ("Felicidad") debe haber leído la brasileña. Aunque son dos historias totalmente distintas, el placer estetico que experimenta la Bertha de Mansfield al contemplar desde su ventana un peral en pleno florecimiento es igualmente íntimo, imposible de compartir. Así lo comprende, en outro contexto, la Clarice narradora que, al sentarse sobre la hamaca y balancearse con el libro abierto sobre el regazo, se convierte "en una mujer con su amante". Hermosa metáfora del acto de leer que es, como dice Gloria Prado, "hacer el amor con el texto", una cópula que Clarice Lispector va a sostener, infinita, ardiente y libremente, con el hombre genérico que está en las palabras. ${ }^{1}$ (Woodward, 2002, 24-25)

Em "Bliss" narra-se episódio intrigante da vida de Berta que, a certa altura da vida, se vê contagiada por inexplicável comoção, deixando-se render pelo impulsivo êxtase. A narradora da história, a exemplo do da anterior, enleia seu discurso à voz da personagem principal. $\mathrm{O}$ êxtase parte do início do conto e sem maiores justificativa se enuncia:

O que pode alguém fazer quando tem trinta anos e, virando a esquina de repente, é tomado por um sentimento de absoluta felicidade - felicidade ab-

O conto que em sua primeira versão se intitulou "Tortura e glória", é também uma pequena homenagem à célebre escritora neolandesa, cujo texto "Bliss" (Felicidade) talvez tenha lido a brasileira. Ainda que seja duas histórias totalmente distintas, o prazer estético que experimenta Bertha de Mansfield ao contemplar, de sua janela, uma pereira florida é igualmente íntimo, impossível de compartilhar. Assim o compreende, em outro contexto, a Clarice narradora que, ao sentar-se sobre a rede e balançar-se com o livro aberto sobre o colo, se converte "em uma mulher com seu amante". Bela metáfora do ato de ler que é como diz Glória Prado. (Woodward, 2002, pp. 24-25) 
soluta! - como se tivesse engolido um brilhante pedaço daquele sol da tardinha e ele estivesse queimando o peito, irradiando um pequeno chuveiro de chispas para dentro de cada partícula do corpo, para cada ponta de dedo? (Mansfield, 2000, p. 11)

Essa seria apenas algumas das passagens da narrativa de Katherine Mansfield que nos remete ao conto "Felicidade Clandestina", vista a estreita relação que pode ser estabelecida entre as duas personagens, levando-se em conta o que ambas escritoras têm em comum, entre outras, a preferência pelos elementos da própria natureza humana aclimatados em ambientes domésticos.

Para Eneida de Souza, "cenas domésticas e aparentemente inexpressivas para elucidação dos fatos históricos passam a compor o quadro das pequenas narrativas, igualmente responsáveis pela construção do sentido subliminar da história." (Souza, 2002, p.115). Assegura que a literatura rica em cenas dessa natureza e pródiga na arte das subjetividades é convocada a servir de corpus analítico para o discurso histórico o que contribui para a exploração de narrativas ficcionais. Ou como afirmou Virgínia Woolf em Orlando, $o$ ato mais vulgar do mundo, como o de sentar-se a uma mesa e aproximar o tinteiro, pode agitar mil fragmentos díspares, ora iluminados, ora em sombra, pendentes, oscilantes, e revirando-se como a roupa branca de uma família de quatorze pessoas, numa corda ao vento. (...) nossos atos mais comuns estão envoltos num tremular e palpitar de asas, num apagar e acender de luzes. (Woolf, 1992, p. 174)

Por meio da mesma ficção evocadora da felicidade, Clarice estabelece, sem contudo eleger, relações com outra de suas precursoras: Virgínia Woolf. No texto, também com o título "Felicidade", datado de 16 de março de 1925, Woolf, do mesmo modo que Mansfield e Clarice, dramatiza, a partir do íntimo das mentes das personagens, suas percepções e seus modos de estar no mundo. E, nos devaneios, o que modela a narrativa é uma linha de análise bastante sutil em que o pensamento do narrador é o próprio fio condutor. Através dele, a autora questiona a arbitrariedade da palavra felicidade: "mas seria 'felicidade'? Não. A grande palavra não parecia apropriada, não parecia referir-se à condição de estar enrolado em róseos flocos ao redor de uma luz vívida." (Woolf, 1992, p. 174)
O conto, como os dois citados anteriormente, tem estados de êxtases narrados com a mesma intensidade a partir de sutilezas quase imperceptíveis, em cenas que também podem ser consideradas domésticas, tendo as vozes das personagens idênticas à voz do narrador. Os dois protagonistas, um homem e uma mulher, têm dentro da mente essa voz e, apresentam suas emoções à medida em que os fatos se desenrolam.

Quando Stuart Elton inclinou-se e sacudiu com um piparote uma linha branca das calças, este simples gesto que foi acompanhado por um deslizamento e avalancha de sensações, assemelhou-se a uma pétala caindo de uma rosa, e Stuart Elton, aproximando-se para reatar a conversa com Mrs. Sutton, sentiu-se formado por muitas pétalas compactadas com firmeza umas sobre as outras, todas avermelhadas, todas aquecidas e coloridas por aquele inexplicável fulgor (p. 173).

O círculo estabelecido entre as duas personagens é inevitável. O conto, praticamente sem ações, não avança em sua narrativa, apenas a memória e a imaginação fornecem às mesmas, meios de se interagirem, o que difere especialmente do conto em cotejo de Clarice, em que uma trama, com causa e consequência, desenrola-se para que a felicidade seja brindada. 
Em Virgínia a felicidade é o espaço onde a história acontece:

$\mathrm{Na}$ felicidade existe sempre essa exaltação aterradora. Não se trata de bom humor; nem de arrebatamento; nem de louvor, fama ou saúde (ele não andava três quilômetros sem se sentir cansado), é um estado místico, um transe, um êxtase que, embora fosse ateu, cético, pagão e todo o resto, tinha [,] ele suspeitava [,] alguma afinidade com o êxtase que transformou homens em sacerdotes, fez mulheres na primavera da vida se arrastarem pelas ruas com afetados folhos semelhantes a cíclames nas faces, lábios cerrados e olhos pétreos. (Woolf, 1992, p. 175)

O exercício de vivenciar por completo a natureza humana e entrar em sintonia direta e absoluta com o movimento harmônico da vida, é também marca indelével na obra de Clarice, embora esta pasmava-se quando diziam que sofrera influência de Virgínia Woolf. A amiga Olga Borelli reforça a negativa:

Na verdade, nenhum autor a influenciou. Sua linguagem era fruto de uma experiência direta dela consigo própria e com o mundo, sem a intermediação disso que se chama - enquan- to sistema organizado de textos de uma determinada cultura - de 'literatura'. (...) Nela, a matéria a pesquisar eram os sentimentos, as sensações, as intuições provocadas pelo simples fluir da vida. (Manzo, 1997, pp. 24-25)

Em carta enviada a Lúcio Cardoso, em que declara sua insatisfação a respeito da crítica feita ao livro Perto do coração selvagem, reconhece que lera Joyce e Woolf, porém só depois da já citada obra estar pronta. Seria uma tentativa de manter seus precursores a uma distância segura?

Imagine que depois que li o artigo de Álvaro Lins, muito surpreendida porque esperava que ele dissesse coisas piores, escrevi uma carta para ele, afinal uma carta boba, dizendo que eu não tinha 'adotado' Joyce nem Virgínia Woolf, que na verdade lera a ambos depois de estar com o livro pronto. (Manzo, 1997, pp. 24-25)

Para Harold Bloom, essa resistência é bastante comum. Os poetas, os críticos, como também os estudiosos, ninguém fica contente em ser influenciado, "Ser influenciado é ser ensinado e, se é certo que todos nós, em qualquer idade, precisamos continuar aprendendo, toleramos cada vez menos que nos ensine alguma coisa." (Bloom, 1991, p. 113) Categoricamente, afirma o mesmo autor "não se ganha nada em continuar a idealizar a leitura, como se ela não fosse uma arte de guerra defensiva. A linguagem poética faz do leitor forte o que ela bem entende, e ela escolhe fazer dele um mentiroso" (p. 136). Desse modo, enquanto leitora-escritora, os artifícios usados para escamotear as influências advindas de Woolf, pressupõe-se, foram vãos. O modo de engendrar os textos e elaborar o tecido literário são idênticos em ambas as autoras. Em Clarice, a experiência do estado de felicidade é implicado por uma ação quase transgressora, um livro tomado como empréstimo sob a obrigatoriedade da mãe da detentora do bem. A felicidade para ela era amoldar-se a um estado e não a uma condição. Como a frase que ousou acrescentar no texto "Felicidade Clandestina" após sua primeira publicação no Jornal do Brasil com o título "Tortura e Glória": "a felicidade sempre iria ser clandestina para mim." (p. 12) Ou como expressou em outra oportunidade: "a extrema felicidade se parece tanto com a infelicidade. Ambas são dramáticas. Ambas são a vida." (Borelli, 1981, p. 19) Para ela, o estado de êxtase não se dispõe à dicotomia felicidade/ infelicidade, mas não encobre o saber tácito da existência da infelicidade que pode corroer o instante feliz. 
No caso dos três contos, ambas as personagens vivem uma experiência de revivificação permeados por efeitos estilísticos que as três escritoras têm em comum. A solução internalizada da questão felicidade seria o elo de ligação entre os três textos que potencializam o amor como expediente mais eficaz para se garantir a felicidade perfeita em uma realidade não perfeita. Para Clarice, do sonho de felicidade para o horror, é apenas um passo. O que vale relembrar suas palavras na crônica "Medo do desconhecido":

E o que é que eu faço? Que faço da felicidade? Que faço dessa paz estranha e aguda, que já está começando a me doer como uma angústia, como um grande silêncio? A quem dou minha felicidade, que já está começando a me rasgar um pouco e me assusta? Não, não quero ser feliz. Prefiro a mediocridade. (Lispector, 1999, p. 35)

A voz da mulher madura que lança o olhar sobre o próprio modo de viver é tão doce quanto amarga, "por algum motivo secreto sinto uma grande carga de mal estar e ansiedade quando atinjo o cume nevado de uma felicidade-luz. Dói no corpo o ar purificado demais" (Lispector, 1978, p. 36). Para a protagonista encontrar a felicidade, fez-se necessário um relacionamento desencontrado com a filha do dono da livraria. Clarice não deixou de traçar o ser humano como imperfeito. De modo crítico, olhando para a menina e narrando seu potencial de perversidade; de modo autocrítico, olhando a si mesma e considerando-se imperdoável ao despertar o ódio da antagonista que não fazia parte de um grupo de meninas bonitinhas, esguias, altinhas e de cabelos livres. Essa condição de precariedade humana, cuja tessitura abarca alguns componentes essenciais para a felicidade, acarreta o inconformismo com a imperfeição e disto nasce a esperança do sonho, do ideal que, no caso, está relacionado com Monteiro Lobato. Provavelmente, a menina teria de fazer a devolução do livro enquanto objeto, mas recusou-se a dramatizar esse episódio e concentrou a felicidade como parte final do conto. Segundo Cunha, "A felicidade é manifestamente qualquer coisa de perfeito e de suficiente enquanto é o fim de todas as ações por nós realizadas." (Cunha, 2000, p. 58)

Para Woodward,
Clarice y sus personajes también buscan la felicidad, ese estado del ànimo que se complace en la posesión de un bién, la satistacción en medio de las frustaciones que a diario impone la realidad mezquina. Pero ella no habla de la felicidad platónica en la virtud, o de beatitud del sabio, sino más bien de aquella que procede de la vida misma, según Plotino, y se realiza en la propria persona, en esse caso como un placer secreto, clandestino, que sólo reconoce quien la disfruta. (Woodward, 2002, p. 24) ${ }^{2}$

O conto que contempla "Clarice e seus personagens" preserva no texto o conceito de autor como ator no cenário discursivo, considerando-se o seu papel como aquele que ultrapassa os limites do texto e alcança o território biográfico, histórico e cultural. Ela aceita esse pacto. Não apenas em "Felicidade clandestina" como em toda sua literatura. Difícil dissociar a obra, do lugar, do autor, do nome. A identidade pode ser a diferença entre todos esses itens. O nome Clarice Lispector pode ser uma palavra título de livro, como em $A$ hora da estrela, ou um signo onde se cruza diversas relações. Pode

\footnotetext{
$2 \quad$ Clarice e seus personagens buscam a felicidade, esse estado de ânimo complacente na possessão de um bem. A satisfação em meio às frustrações que a realidade impõe diariamente. Porém ela não fala da felicidade platônica na virtude, ou da bem-aventurança do sábio, mas sim daquela que procede da vida mesmo, segundo Plotino, e se realiza na própria pessoa, nesse caso como um prazer secreto clandestino, que só reconhece quem o desfruta. (Woodward, 1999, p. 24. Tradução minha.)
} 
ser a mulher dinâmica e social, ou um lugar imaginário. Também pode tomar o posto de uma personagem e intrometer-se na própria trama de maneira insólita e sem explicações, como na obra Onde estivestes de noite: "a velha era anônima como uma galinha, como tinha dito uma tal de Clarice (...) Essa Clarice incomodava" (Lispector. 1999, p. 38). Em A mulher que matou os peixes, falando confortavelmente em primeira pessoa, ela diz: "Essa mulher que matou os peixes infelizmente sou eu. Mas juro a vocês que foi sem querer. (...) Antes de começar quero que vocês saibam que meu nome é Clarice. E vocês, como se chamam?" (Lispector, 1977, pp. 7-10)

A escrita de Lispector propõe as fabulações como recorrência à escrita de si em um certo espaço e tempo. Ou seja, um tornar a contar, pois a vida a que supostamente se refere é por si mesma uma construção narrativa, como adverte Molloy,

a vida é sempre, necessariamente, uma história que contamos a nós mesmos como sujeitos, através da rememoração. (...) A linguagem é a única maneira de que disponho para "ver" minha existência. Em certo sentido, já fui "contado" - contado pela mesma história que estou narrando. (Molloy, 2003, p. 19)
Em sua obra, diversas naturezas unificam-se em variados propósitos que tem como locus enunciativo personagens, narradores, relatos de conversas com choferes de taxi e empregadas domésticas, cartas aos amigos, observações em talões de cheques e uma gama de textos escritos sob a tipologia de literatura infantil. Movimentou-se sobre uma rede discursiva das mais ricas, como é o caso dos contos, até uma fragmentária gama de anotações encontradas entre as crônicas de A descoberta do mundo. Clarice é mais que um estilo, parte do improvável, da investigação dos desejos até ao resgate do cotidiano, da restauração de objetos e coisas tão comuns que chegam a nos impor um outro modo de leitura, obrigando-nos a alinhavar toda essa produção ao fio da memória. Para Woolf, "a memória é a costureira, e costureira caprichosa. A memória faz a sua agulha correr para dentro e para fora, para cima e para baixo, para cá e para lá." (Woolf, 1978, p. 44)

Nesse exercício vamos tentando encontrar na voz de Clarice autora, outras tantas Clarices que ora aparecem, ora fogem, escapam e parecem rir de todos nós: "Muita coisa não posso te contar. Não vou ser autobiográfica. Quero ser 'bio"”. (Lispector, Água viva 1998, p. 33)

O leitor sempre se deparará, em cada personagem, com o refle- xo de Clarice a interferir na forma de decodificação de sua obra. Se seguirmos as linhas condutoras dos discursos clariceanos, chegaremos a um lugar em que a verdade só existe sob a forma de ficção, ou seja, a verdade é a forma ficcionalizada da experiência da escrita. As conclusões de Clarice sugerem interrogações, muitas vezes não explícitas, sobre algo escondido, apenas conjecturado, "objeto gritante que está atrás do pensamento". Ela nunca cessou de explorar os caminhos possíveis do fazer literário, como se quisesse desarmar a última palavra de seu próprio artifício. Esteve perto do coração selvagem a escutar os sentimentos mais comuns, chegou ao nada durante a mística paixão segundo G.H. Seus olhos úmidos de água viva refletiram a luta da escrita contra o tempo e contra a morte, mas reconheceu no instante impalpável a possibilidade do êxtase e viveu uma espécie de felicidade clandestina em que o próprio ato de escrever é vivido e revelado em um estado de consciência exaltada, exacerbada, que evoca uma singular e solitária experiência mística. Seria uma aprendizagem ou a descoberta do mundo? A mulher que matou os peixes, e que se chama Clarice, descobre o Brasil. As angústias existenciais, a cultura brasileira em suas múltiplas expressões, a realidade do nordestino desajustado e trágico ajudam-na 
a refletir sobre a última hora, a hora que pode ser dramática, mas que pode também ser a única verdade desta mulher, a verdade estrangeira que buscou no início da vida e perseguiu nos últimos anos. Na hora da estrela "a identidade do Eu convencional foi trocada pela identidade real com a matéria da vida. Esse trânsito é sentido como desgaste, como perda irreparável da própria substância humana, que se abriu para conter a substância universal. Clarice se vai, entretanto deixa um sopro de vida. E ainda que muitos anos tenham se passado após sua morte, vale considerar a definição mais precisa que fez de si mesma: "eu sou uma pergunta." (Lispector, 1999, p. 367)

Foi uma escritora que militou entre a linha interna de sua personalidade e a linha de sua escritura, entre a razão e a falta da razão, tirando proveito de ambos os lados para a construção de seu projeto literário, foi a transfiguração do ser dentro do ser, recordando que quando a voz do ser (eu) se calava, crescia a voz do silêncio, essa voz tão bem manipulada por Clarice.

\section{Considerações finais}

Especificamente, a escrita de "Felicidade clandestina" é uma narrativa que se deixa contar em forma de ficção, que nasce de uma felicidade da palavra - o que não deve ser confundida com uma palavra feliz, pelo contrário, pois perderíamos o contorno e o contraste da mesma, mas uma felicidade que tenciona fixar na materialidade da palavra o abstrato da vida, captar o instante mediante o diluir do tempo. Clarice e suas personagens buscam a felicidade, esse estado de ânimo complacente na possessão de um bem. A satisfação depois de várias frustrações, que é o que a realidade impõe no dia-a-dia. Porém, Clarice não fala de uma felicidade platônica nascida na virtude, como sugere os contos de fadas e as fábulas, nem da bem-aventurança relacionada ao bom comportamento, mas daquela que procede da vida mesmo e se realiza na própria pessoa como um prazer secreto, clandestino, que só reconhece quem o desfruta.

Nesse ponto, mulher e obra se bifurcam, se contaminam mutuamente, porque a mulher quer suportar a linguagem até às últimas consequências, até onde a palavra permite o prazer místico da escritura. Clarice força o gênero literário até transformá-lo em meio de expressão de sua subjetividade. $\mathrm{O}$ ato de escrever alcança o momento mais secreto e a felicidade é um instante clandestino, nem sempre perceptível a todos, vide a menina "filha do dono da livraria", detentora do livro, mas sem capacidade de fruição.

Ler o texto de Clarice Lispector a partir de uma perspectiva crítico-biográfica é emaranhar-se numa teia de linguagem e enredar-se numa refinada trama de signos que dialogam com lugares, épocas e abarcam fronteiras reais e imaginadas. Impossível sair ileso desse embate em que narrador, personagens e leitor se misturam, num jogo especulativo em que palavras e imagens, sons e silêncio se combinam segundo uma lógica complexa, criadora de objetividade e subjetividade. É a vida apropriando-se da ficção e vice-versa. Através da crítica biográfica é possível certificar-se do papel que o escritor ocupa na sociedade e como é capaz de experimentar isso em sua obra. 


\section{Referencias}

Barthes, R. (2002). O prazer do texto. Trad. J. Guinsburg. 3. ed.São Paulo: Perspectiva.

Barthes, R. (1977) Barthes por Roland Barthes. Trad. Leyla Perrone-Moisés. São Paulo: Cultrix.

Bloom, H. (2002). A angústia da influência: uma teoria da poesia. Tradução: Marcos Santarrita. Rio de Janeiro: Imago, 2ed.

Bloom, Harold. (1991) Cabala e crítica. Trad. Monique Balbuena. Rio de Janeiro: Imago, 1991.

Borelli, Olga. (1981) Clarice Lispector: esboço para um possível retrato. 2.ed. Rio de Janeiro: Nova Fronteira.

Cioran, E. M. (2000). Exercícios de admiração: ensaios e perfis. Trad. José Thomaz Brum. Rio de Janeiro: Rocco.

Cunha, D. (2000). A amizade segundo São Tomás de Aquino. Cascais: Principia, Publicações Universitárias e científicas.

Duras, M. E. (1994). Trad. Rubens Figueiredo. Rio de Janeiro: Rocco.

Foucault, M. (1992). O que é um autor? Trad. de José A. Bragança de Miranda e António Fernando Cascais. Lisboa: Veja, Coleção Passagens.

Gotlib, N. B. (1995). Clarice: Uma vida que se conta. 2. ed. São Paulo: Ática.

Ferreira, T. C. M. (1999). Eu sou uma pergunta: uma biografia de Clarice Lispector. Rio de Janeiro: Rocco.

Iannace, R. (2001). A leitora Clarice Lispector. São Paulo: Edusp.

Lispector, C. (1998). Felicidade clandestina. Rio de Janeiro: Rocco.

Lispector, C. (1999). A descoberta do mundo. Rio de Janeiro: Rocco.

Lispector, C.(1999). Para não esquecer. Rio de Janeiro: Rocco.

Lispector, C. (1998). Água viva. Rio de Janeiro: Rocco.

Lispector, C. (1998). Onde estivestes de noite. Rio de Janeiro: Rocco.

Lispector, C. (1978). Um sopro de vida: pulsações. 6.ed. Rio de Janeiro: Editora Nova Fronteira. 
Lispector, C. (1977). A mulher que matou os peixes. Rio de Janeiro: Francisco Alves.

Mansfield, K. (2000). Felicidade e outros contos. Tradução: Julieta Cupertino. Rio de Janeiro: Editora Revan, $3^{\mathrm{a}}$ ed.

Manzo, L. (1997). Era uma vez: eu - a não ficção de Clarice Lispector. UFJP. Curitiba: Secretária de Estado da Cultura.

Molloy, S. (2003). Vale o escrito: a escrita autobiográfica na américa hispânica. Trad. Antônio Carlos Santos. Chapecó: Argos. (Vozes Vizinhas. Os melhores ensaios).

Ortega, F. (1999) Amizade e estética da existência em Foucault. Rio de Janeiro: Edições Graal.

Ortega, F. (2000). Para uma política de amizade: Arend, Derrida, Foucault. Rio de Janeiro: Relume Dumará.

Souza, E. M. (2002). Crítica cult. Belo Horizonte: Editora UFMG.

Souza, E. M. (1999). O século de Borges. Belo Horizonte: Autêntica/Rio de Janeiro: Contra Capa Livraria.

Woolf, V. (1992). Objetos sólidos. Tradução: Hélio Pólvora. São Paulo: Siciliano.

Woolf, V. (1978). Orlando. Trad. Cecília Meireles. Rio de Janeiro: Nova Fronteira.

Woodward, M. C. (2002). Org. Cuentos reunidos: Clarice Lispector. Trad. Cristina Peri Rossi, Juan García Gaió, Marcelo Cohen, Mario Morales. Madrid: Alfaguara. 